\title{
Uninterested Youth? Young People's Attitudes towards Party Politics in Britain
}

\author{
Matt Henn, Mark Weinstein and Sarah Forrest
}

\author{
Political Studies
}

\author{
Vol. 53 (3), pp.556-578. 2005 \\ DOI: $10.1111 / j .1467-9248.2005 .00544 . x$
}

\begin{abstract}
Following the outcome of the 2001 and 2005 General Elections, when the numbers of abstainers outweighed the numbers of Labour voters on both occasions, much attention has focused upon the state of British democracy and how to enthuse the electorate, especially young people. While the government is exploring ways to make the whole process of voting easier, it may be failing to tackle the real problem - that youth appear to find the business of politics uninviting and irrelevant. This paper examines data derived from a nationwide survey of over 700 young people in order to shed light on what lies at the heart of young people's apparent disengagement from formal politics in Britain - political apathy or a sense of political alienation. The findings reveal that they support the democratic process, but are sceptical of the way the British political system is organised and led, and are turned off by politicians and the political parties. However, there is no uniform youth orientation to politics, and the data indicate that views differ according to social class, educational history, and also gender. However both ethnicity and region of the country in which young people live seem to have little influence in structuring political attitudes and behaviour.
\end{abstract}

The landslide re-election of the Labour party to national government at the 2001 British General Election was over-shadowed by the lowest voter turnout rate since 1918, and has led some to claim that Britain is experiencing a "crisis of democratic politics" (Harrop, 2001, pp.295-313). Yet, the aggregate figure of 59.4 per cent $^{1}$ (down from 71.6 per cent at the previous General Election in 1997) itself masked important differences in rates of electoral participation within the electorate. Voter turnout was lowest in constituencies of relatively high socio-economic deprivation, such as Liverpool Riverside (34 per cent) and Glasgow Shettleston (39 per cent), and amongst marginalized groups such as ethnic minorities (47 per cent) (MORI, 2001, p.3). With only 39 per cent of eligible 18 to 24 year olds voting in 2001 (a reduction of 27 per cent since 1997), political "disconnection" is broadly considered to be particularly acute amongst young people (Norris, 2001; Henn et al., 2002), a trend that has been identified across all European states (European Communities, 2003). As a response and in an attempt to re-engage the electorate, the Government revised the electoral procedures to simplify and extend postal voting at the 2005 general election. Yet even with the massive increase in postal voting (estimated to have increased from 1.4 million to around five million (Travis 2005, p.1)) overall adult 
turnout increased only marginally by 1.9 per cent to 61.3 per cent, and significantly continued to fall for youth voters (to only 37 per cent).

\section{Assessing Young People's Political Engagement}

Academic research into youth political engagement is relatively new within British political science, ${ }^{2}$ and until very recently studies have tended to use broadly quantitative attitudinal and behavioural measures. These studies have presented findings that seem to indicate that young people in Britain are a generation apart when it comes to political attitudes and to political participation rates. Data suggest that not only do young people turn out in lower numbers to vote than do their older counterparts, they are also less likely to register to vote in the first place (Russell et al., 2002). Other studies have concluded that: young people have lower-levels of political knowledge than do older age groups; have a distinct lack of interest in (formal) politics; display comparatively weak commitments to political parties; and are less likely than older people to be members of such organisations (Parry et al., 1992; Park, 2000; Kimberlee, 2002). Indeed, the message from many quantitative-based studies tends to suggest that young people's levels of political participation in general are in decline, and at a somewhat more rapid rate than is the case for their older contemporaries and previous youth cohorts (Pirie and Worcester, 2000). Furthermore, young people can be differentiated from wider society in terms of their political attitudes and views - they are considered to be less materialistic (Mulgan and Wilkinson, 1997; Bennie and Rudig, 1993) and less conservative than older contemporaries, ${ }^{3}$ and highly disillusioned with the operation of politics and cynical of politicians (Wring et al., 1999). The broad conclusion drawn is that young people are becoming increasingly disconnected from the political set-up, and politically apathetic.

The essentially quantitative approach used in these studies reflects what Henn et al characterise as "conventional political science" (2002, p.170), and what O'Toole et al refer to as the "mainstream survey-based" approach (2003, p.46). Such studies have been criticised on methodological grounds for using purely closed questions as indicators of political attitudes and levels of political participation, and for assuming the existence of a shared understanding of political concepts between researcher and survey respondent (Roker et al., 1999; Henn et al., 2002; O'Toole et al., 2003). They have also been criticised for working within a very narrow conception of 'formal' politics - a politics that is concerned with the formal institutions of government, the main British political parties, and traditional forms of political behaviour such as voting in elections, attending political meetings, and membership of overtly political organisations (Henn et al., 2002). Indeed, Seyd and Whiteley (2002, p.1) employ a definition of political participation as "activities by individuals aimed at influencing the policies or personnel of the state and government... such as campaigning, organising, fund-raising, and attending meetings as well as seeking elected office". Furthermore, they claim that all types of politics necessarily involve established organisations: political activism (2002, p.2):

\section{...is impossible without institutions, since individuals acting alone cannot change state policies... Creating the cooperative behaviour that underpins collective action requires actors to have a stable set of expectations about each other, and this can only be fostered in institutions.}

Results from more qualitative-based studies present a different picture- that young people are concerned about matters that are essentially 'political' in nature, and that they do take part in various types of 'political' activity, which nonetheless neither they 
nor mainstream political science would necessarily classify as 'political'. ${ }^{4}$ For example, Roker et al (1999) revealed a high level of volunteering, campaigning and other social action activities that the young people carrying out these acts did not consider to be 'political'. More recently, Eden and Roker $(2002$, p.7) have developed a concept of 'constructive social participation' carried out within a number of different groups including: youth sections of larger organisations such as the youth wing of the Campaign for Nuclear Disarmament and the trade unions; youth councils, support and campaign groups such as young carers, young people with disabilities, lesbian, gay and bisexual groups; and community-based groups such as crime, safety, and health groups. The participation that they uncovered encompassed a wide variety of social actions including formal voluntary work, informal community networks, neighbourliness, informal political action, awareness-raising, altruistic acts, and caring work at home and in the community through which young people 'participate in their communities and influence policies and practices in the world around them'. In addition, two recent quantitative studies indicate that young people are more likely to engage in 'cause-oriented' styles of politics (Norris, 2003) and 'micro-politics' (Pattie et al., 2003) than they are in 'formal' politics.

Nonetheless, the general message that youth in Britain today are politically disengaged is one that seems to hold particular sway within academic and policy circles alike (Department of the Environment, Transport and the Regions, 1998). Consequently, there is a concern amongst politicians and officials that this age group have a disaffection from politics that is deeply entrenched; that in the medium- to long-term, the more civicoriented older generations will be replaced by this younger sceptical generation, and that the legitimacy of the political system is itself therefore under threat (Mulgan and Wilkinson, 1997).

\section{Explaining Young People's Political (Dis)engagement}

But what is the source of this apparent aversion to formal politics that young people are alleged to have? In a recent article, Kimberlee (2002) usefully distinguishes four approaches to the study of specifically young people's engagement with politics in Britain identified in the literature, although no empirical evidence is provided to arbitrate between these. The first 'youth focused' approach is associated with traditional 'lifecycle' explanations (Verba and Nie, 1972; Parry et al. 1992), and suggests that young people are chronically politically apathetic as a consequence of their individual life-styles and of various 'start-up' problems that confront them. These life-style and contextual circumstances include increased mobility, lack of long-term attachments to neighbourhoods, and ultimately an absence of patterns of electoral registration and voting (Kimberlee, 2002, p.87). Recent research by Norris (2003) finds persuasive evidence in support of this life cycle interpretation in relation to conventional political participation.

A second 'politics focused' explanation is centred on the premise that the political system is failing to provide the stimuli necessary to encourage young people to turn out and vote (Kimberlee, 2002, pp. 88-90). According to this position, the nature of British politics itself is changing, with political parties and professional politicians adopting increasingly centralised and marketing-led campaigning methods. Typically, these methods involve focusing their attentions on key groups of voters whose support is most likely to yield maximum electoral dividends - these groups often do not include young people. As a consequence, the campaigning strategies adopted by political parties tend to be geared 
more toward middle-aged, middle England voters (Kimberlee, 1998). Furthermore, in pursuit of 'catch-all' vote-maximising electoral strategies, political parties have become increasingly pragmatic in outlook, and are perceived to have become bereft of ideas that mark them out as distinct from their rivals. ${ }^{5}$ In this process, young people's views tend to become marginalised by the parties, leading them to draw the conclusion that political parties are remote and irrelevant (Kimberlee, 2002, p.90).

Kimberlee (2002) outlines two further positions that seek to explain young people's lack of engagement with formal politics. An 'alternative value' account suggests that young people have a distinct political agenda beyond the ambit of the main political parties in Britain. This 'New Politics' agenda leads young people to reject conventional political parties and their programmes, and to prioritise instead single issue campaigns and New Social Movements. This approach, drawing on the works of Inglehart (1990), Dalton (1988) and others is, however, a highly contested one. Bennie and Rudig (1993), for example, argue that whilst young people may be more likely to express views sympathetic to the environment they are less likely to engage in pro-environmental political activity. Similar evidence is provided by Norris (2003), suggesting that whilst there appears to have been a generational shift towards sympathy with and participation in some 'cause-oriented' actions, youth membership of such associations is not markedly higher than that for the general population. There are also severe measurement problems in relation to participation in such types of political activity given the fragmented and loose nature of many of those involved in the direct action movement in Britain (Furlong and Cartmel, 1997; Weinstein, 2003). It suggests that young people are politically engaged, but eschew formal politics and voting in favour of a new type of politics.

Finally, a 'generational' explanation suggests that the world in which today's young people find themselves is not conducive for the development of their active engagement with and participation in, the British political system (Kimberlee, 2002). The transition to adulthood (which includes the acquisition and expression of political understanding and rights) is comparatively more lengthy, complex and risky than was the case for previous youth generations, and there are fewer mechanisms available to transmit knowledge about the world of politics to youth than there were in the past. ${ }^{6}$

In this article, we aim to examine whether there is any substance to the claim that youth in Britain are politically disconnected and apathetic. In doing so, we shall adopt an approach that borrows from Kimberlee (2002), addressing the 'youth focused', 'politics focused', and 'alternative value' explanations he outlines. We shall not engage with the 'generational' explanation, as to do so is beyond the bounds of our data. Kimberlee's work lacks the empirical evidence necessary to arbitrate between these positions, and our data will be used for this purpose, employing his approach as an organising framework for our analysis. The intention here is two-fold. First, to identify the processes at work behind the orientation that young people have toward British politics. Secondly, to shed further light on whether or not there is indeed a crisis of democratic legitimacy in Britain in terms of the attitudes of young people toward political structures, institutions, and players (especially the political parties).

In order to test the 'youth focused' approach, we shall explore the extent to which that model's general conclusions - that young people are politically disconnected, with little interest in political issues, institutions and processes - are reflected in our findings. For this purpose, we employ several questions which tap into young people's understanding 
and self-definition of politics, their interest in politics, whether or not they display an engagement with any particular political issues, their support or not for the democratic and electoral processes, and their general levels of political activity. The "politics focused' model shall be examined by considering responses to several questions concerning their attitudes towards the political parties and professional politicians. Do they display any meaningful identification with the political parties? How much trust and confidence do they have in political parties and their representatives? Do they consider that these agencies faithfully articulate and represent the interests of young people like themselves? Finally, the 'alternative value' model shall be assessed by investigating young people's responses to questions concerning their issue priorities and political agenda, as well as their preferred style of politics.

In conducting these analyses, we aim to avoid making any potentially spurious claims that we can naturally generalise from our findings to all youth in Britain, as if this generation is a homogenous group. It is therefore important for the research design to adopt an analytical approach that is sensitive to the possibility that differences may exist within this generation in terms of their levels of political engagement. This will involve undertaking sub-group analysis to ensure that we do not inadvertently generalise our findings in an unreliable manner. Historically, research of all voting-age adults in Britain has identified an increasing heterogeneity over time in terms of their orientation to politics (Butler and Stokes, 1974; Parry et al, 1992). Accordingly, recent empirical studies suggest that people's socio-demographic backgrounds need to be taken into account if we are to understand their political outlook and orientation. Thus, even though the twin processes of class and partisan dealignment are generally considered to be symptomatic of the diminishing influence of social class on political engagement, there is still considerable evidence that this variable does in fact continue to exert an impact on people's political preferences and behaviour (Evans et al., 1999). Similarly, Norris (1999) evidences a continuing gender gap in British electoral politics, although this has an age dimension, with young women more likely than their male counterparts to support the Labour party, and older women more likely than men to vote for the Conservatives. Lovenduski (2001, p.189) suggests that, "women are more likely [than men] to intend to vote, less likely to express satisfaction with the government, and more likely to be floating voters". Recent studies also point to ethnicity as a major political cleavage in British political behaviour, with members of BMEs having lower registration and voter turnout rates than, and displaying different political loyalties from, their white counterparts ${ }^{7}$ (Saggar and Heath, 1999). As well as social class, gender and ethnicity, evidence suggests that educational history (Bynner and Ashford, 1994), and place in which people live (Curtice and Park, 1999) are also important variables that influence people's political engagement. We will use these same five variables to investigate the extent to which the 'youth focused', 'politics focused', and 'alternative value' models are relevant for furthering our understanding of young people's attitudes towards party politics in Britain. Is there a particular 'youth' outlook, or a multitude of outlooks?

\section{Research Design}

The data are derived from the first ever nationwide study of the political attitudes of attainers-young people eligible to vote in an election for the first time. ${ }^{8} \mathrm{We}$ conducted a postal questionnaire survey of 705 young people that included a mix of both closed and open-ended questions. In order to generate our responses, we used a random sampling method, with respondents drawn from the electoral register. ${ }^{9}$ The 
sample was stratified by Government Standard Region, and within that by ACORN ${ }^{10}$, securing a geographically and socio-economically representative sample. ${ }^{11}$ We mailed 3,200 respondents ${ }^{12}$ an eight-page questionnaire direct to their home addresses in the Spring of 2002. Three recall surveys were conducted, and in total 705 questionnaires were returned. ${ }^{13}$ A final response rate of 23 per cent was therefore achieved, which represents a satisfactory return for a postal survey of this nature. The data were then weighted to take account of the distribution of the British youth population across the key variables of region (and nationality), gender, social class, and ethnicity, and to ensure that our aggregate results did not over- or under-reflect the views of people from different socio-demographic groups. Tests confirmed that the weighted and unweighted data were closely matched, indicating that our survey results have good external validity and generalisability. Whilst we would have welcomed a larger response rate, there is no evidence of differential response across the key socio-demographic groups to threaten validity ${ }^{14}$ - the important issue is not the proportion of non-respondents, but the degree to which the survey participants match the wider population (Oppenheim, 1996, p.102).

\section{Results}

Our results are organised under headings that allow us to examine the extent of young people's interest in 'politics', the degree to which they feel that there are opportunities open to participate meaningfully in political affairs, their views on the democratic process and the key political players (political parties and professional politicians), and what they consider might be done to make politics more inviting to young people.

\section{Political Engagement}

As noted earlier, one charge levelled at conventional quantitative political science from some academic quarters is that when measuring political engagement, the emphasis tends to be upon "a very narrow conception of politics and 'the political"' (O'Toole et al., 2003, p.46), determined by the researchers in their use of closed questions. Mindful not to fall into this methodological ambush, we presented respondents with a qualitative open question placed at the beginning of the questionnaire that asked, "When people talk about 'Politics', what does that mean to you, exactly?". This enabled the young people participating within the study to determine themselves, how they understand the world of politics.

We coded respondents' written answers to this question into themes that seemed to capture the essence of young people's understanding and self-definition of Politics. Figure 1 distils these responses. Taking the first item noted in each answer, ${ }^{15}$ it clearly indicates that these young people considered politics to be about "Government" (25 per cent), "How the country is run" (19 per cent), "Talking, debates and arguing" (7 per cent), and "People who take decisions on our behalf" ( 6 per cent). Interestingly, the definition of politics given here by the young people in our survey corresponds very closely with the rather narrow conception of politics taken by mainstream political science. This reflects the findings of White et al. (2000).

Figure 1: What is Politics? about here 
However, an examination of the actual written responses from which these statistics have been derived, reveals that young people's characterisation of politics was broadly negative in orientation; by defining politics as something that occurs elsewhere, by others, involving discussion and debate, the young people who responded meant that they considered politics to be an activity carried out by unrepresentative and selfserving politicians, who operated at a distance from the lives of the general public, engaging in argument that had little relevance for the public at large. The following are typical of the responses given:

$\sim$ Being honest, it does bore me mostly, because the government is so corrupt, unless something significant or interesting is going on I don't pay attention (I don't understand most of it anyway).

The government. Middle aged men in suits who make decisions concerning all sorts of things often in a biased way.

$\sim$ I don't really take much notice, but I guess politics means middle-aged men (elite) who try to run the country. Politics is for a selected group of people.

A group of people trying to run the country. Sometimes they're good at it and most of the time it seems they are just trying to make money for themselves.

Despite their aversion to the world of Westminster (for this is how they themselves define the arena of 'Politics'), young people claim (paradoxically) to be interested in "politics" in general. When asked about politics in general, 56 per cent of respondents ${ }^{16}$ replied that they had some or more interest in the topic (which compares with 13 per cent who had none at all). Furthermore, nearly half (48 per cent) claimed an interest in the General Election held the previous June 2001 (only 17 per cent had no interest at all), whilst a majority (54 per cent) considered that they would discuss politics with friends and family in the future.

By combining the data from a number of questions we were able to derive a 'political interest' variable,${ }^{17}$ which we then tested against a number of key socio-demographics in the study mentioned above. Table 1 presents the results from an analysis using the chi-square test to examine relationships within the data. Evidence of a statistically significant gender gap emerges, with more men than would be expected by chance professing an interest in politics; the opposite is the case for young women. However, social class ${ }^{18}$ in particular, and also educational history exert stronger influences, and the degree of statistical significance is higher for these variables than it is for gender. Young people from middle class managerial/ professional households are significantly more interested in politics than those from other social class households - the majority of this higher social class group report an interest (52 per cent), whilst an overwhelming proportion of young people from manual, unskilled or 'working class' households report a disinterest in or ambivalence to such matters (67 per cent). Whether or not a respondent has chosen to remain in full-time education (Educational career) also has a significant impact on interest levels, with those who had chosen to prolong full-time study more interested in politics than those who had left full-time study at the statutory school leaving age.

Our other 'educational' variable (Qualifications) differentiates those with educational or work-related qualifications from those without. Again, there is a marked difference in the views of these two groups that is statistically significant, with those without such qualifications much less interested in political affairs than their qualified contemporaries. ${ }^{19}$ The other variables examined — region in which the respondent lived 
and ethnicity - exerted relatively little impact on the level of interest expressed by respondents. The former is perhaps surprising, given that Wales, Scotland (1999) and London (2000) have their own additional tier of regional government, and it has been argued that decentralisation and devolution increase voter engagement and participation in elections (Meguid, 2003). However as we shall see, our data indicate that this variable has negligible impact on structuring youth political attitudes across Britain.

That ethnicity does not exert a significant impact on political engagement is also noteworthy, especially given that members of British minority ethnic (BME) groups were markedly less likely to vote at the 2001 General Election as a group than were white respondents. However, political engagement involves much more than just electoral politics - for instance, Norris (2003) notes that in recent times there has been a significant diversification of repetoires of political action amongst young people, which include consumer politics, petitioning, demonstrations, protests, lobbying. We should not therefore assume that BME groups have a generalised lower rate of political engagement than white groups simply on the basis of these 2001 voter turnout figures. Furthermore, there is evidence to suggest substantial internal differentiation within BME groups, with some more likely to vote than other BMEs, and also more likely to vote than white people (Purdam et al., 2002). However, although the construction of our ethnicity variable takes account of the substantial differentiation within BME groups $^{20}$, the sample size of this group is too small for differentiated analysis across the range of BME groups. ${ }^{21}$ Therefore we chose not to conduct detailed analysis of political engagement within BME groups.

\section{Table 1: Political Interest about here}

As a further indicator of their level of political engagement, we asked an open question - "In your opinion, what is the single most important issue at the moment?". Again, this qualitative method provides the respondent with the opportunity to indicate the scope and nature of their concerns, rather than responding to a list imposed by us, reflecting our assumptions of what issues are important to others. Figure 2 is based upon a re-working of this data, using the same thematic grouping method as used for Figure 1 , to summarise the main issue priorities of respondents. It suggests that their agenda is a broad one that embraces a wide spectrum of concerns. Contrary to perceived wisdom that young people have a distinctive 'New Politics' agenda that sets them apart from older adults, the data indicate that their outlook, at least on the surface, is remarkably similar. $^{22}$ Nearly half of our sample prioritised concerns over the public services, the largest group mentioning health as the issue of single most importance to them ( 28 per cent), with others giving precedence to education (14 per cent) and transport (4 per cent). A fifth (19 per cent) of respondents mentioned traditional "materialist" issues (economic matters, Europe, crime and law and order) again, indicating a preoccupation with mainstream concerns. However, an examination of the actual data suggests that in important ways, the perspective that young people bring to some of these issues is at times quite specific - certainly when contrasted with the Westminster discourse. Thus, on the issue of education, young people are less inclined to engage with matters concerning quality, standards and league tables, than they are to express anxieties about the financial implications of taking a university course and with possible student hardship. 
Figure 2: Issues of Most Concern about here

While this data indicate that young people do not display a preference for the 'alternative values' agenda above all others, there is nonetheless, a noticeable minority (13 per cent) who prioritise New Politics concerns about wars and militarism, solidarity with the third world, animal rights, and environmental protection. ${ }^{23}$

Overall, these results seem to run counter to popular thinking that young people are dismissive of 'Politics'. British youth do profess an interest in the world of political issues and current affairs, and in particular demonstrate an engagement with a variety of political issues. This perhaps belies the main tenet of the 'youth focused' approach that characterises young people as politically apathetic.

\section{Political Power and Influence}

Our survey data indicate that young people do not feel that there exist meaningful opportunities open to them to influence the political scene - indeed, an overwhelmingly large majority of respondents considered that they had little or no influence on politics and political affairs ( 82 per cent). Comparing the percentages of those who agreed with those who disagreed on a number of statements concerning this matter, the data reported in Table 2 reveal that attainers felt relatively powerless, politically. They consider that government does not treat them fairly, is deaf to their concerns, and generally unresponsive; consequently, trying to actively engage with and influence government is perceived to be a waste of time.

\section{Table 2: Perception of Political Influence about here}

By combining the results of several questions, we created an external efficacy index. ${ }^{24}$ This demonstrated that only 11 per cent considered that it was indeed possible for young people like themselves to influence the political decision-making world, while seven times as many young people (81 per cent) claimed to lack such influence. It is interesting to note that when subjected to bivariate analysis this very low level of external efficacy was observed across all socio-demographic groups examined (gender, ethnicity, social class, region, educational career and qualifications), except social class, and even in this case, strength of the effect is relatively weak. Taken together, the data reported in Table 3 suggest that young people in Britain today feel uniformly marginalised from the political process, and relatively powerless to influence it. This would seem to correspond with the 'politics focused' model, indicating that young people feel as if the political system remains remote and distant, failing to attract and engage people of their generation.

\section{Table 3: Political Efficacy about here}

Respondents were then asked how likely it was that they might take part in various types of political activity over the next few years. From the responses given, there is little evidence to support the notion that young people consider political activity to have value in terms of increasing their political influence. Consequently very few state that they would be prepared to take part in political activity in the future. Only 16 per cent considered it likely that they would work actively with a group of people to address a public issue or tackle a problem, with a large majority (60 per cent) stating 
that they would be unlikely to take part in such action. Similar numbers (63 per cent) thought it unlikely that they would participate in a protest to show their concern about a public issue or problem. However, many more respondents were prepared to engage in less overtly 'political' activities, with 36 per cent stating that they might in the future be active in voluntary organisations, such as community associations, charity groups, or sports clubs (although, a larger group [39 per cent] thought this unlikely). Interestingly, a sizeable minority ( 20 per cent) responded that they would be prepared to try to convince someone else how to vote, suggesting that for this core group, political parties are worthy of support (although most young people [65 per cent] ruled out this method for promoting the political parties).

We created an 'activism' variable to summarise the responses to this battery of questions and examined the resulting data in more detail. ${ }^{25}$ As Table 4 demonstrates, gender, ethnicity, region in which the respondent lives, and whether or not the young people possess some form of qualifications, do not exert any statistically significant influence on young people's levels of political activism. However, educational career and social class are significantly related to political activism. Those who have remained in full-time education are much more likely to be politically active (31 per cent) than those who are no longer in full-time education (19 per cent); those young people from middle class managerial/ professional households are considerably more likely to be active in politics (31 per cent) than their manual, unskilled or 'working class' counterparts (22 per cent).

\section{Table 4: Political Activism about here}

Nonetheless, there is a relatively low rate of political activity present in our data for all youth, particularly in terms of participation in traditional forms of politics. This may reflect the lack of external efficacy identified earlier, and a sense of pessimism that the costs of such activity outweigh the benefits; if so, this would lend weight to the 'politics focused' model. The relatively larger number of people prepared to engage in less overtly 'political' activity-in more decentralised voluntary and local community activities for example - suggests that the 'alternative values' model has relevance for some youth who are more prepared to engage in alternative styles of activity than in traditional party politics type.

\section{Confidence in the Democratic Process}

Despite feelings of general political powerlessness, young people $d o$ appear to have faith in the democratic process itself, and are generally supportive of the notion of elections. The data reveal that more people said they were satisfied ( 31 per cent) than were dissatisfied ( 26 per cent) with the way democracy works (although 28 per cent held an ambivalent "Neither Satisfied Nor Dissatisfied" view).

In response to a series of questions about elections, young people indicated that they $d o$ have a general attachment to and confidence in the democratic process. As Table 5 demonstrates, they do not consider that elections are a waste of time, and further, that they provide an opportunity for their views to be heard by politicians. Young people clearly have a 'civic imperative', expressing agreement with the sentiment that they would be neglecting their duty as a citizen if they did not vote. Nonetheless, they qualify this by stating that they would only vote if they cared who won - perhaps signalling a caution that parties that converge are likely to alienate young people. This 
general interest in and support for the democratic process would seem to be at odds with the claims made in the 'youth focused' model - that young people's contextual background leaves them in a state of relative political apathy. However, their subsequent caveat that they would only participate in the democratic process should it more obviously yield tangible benefits, would seem to support the 'politics focused' model, indicating that levels of youth political engagement are largely conditional on their perceptions of the process and the resulting outcomes.

\section{Table 5: Support for the Democratic Process about here}

Combining responses from a number of questions into a single index of attitudes to elections ${ }^{26}$ the survey data indicate that young people are relatively evenly divided between those who positively believe in the electoral process (48 per cent), against those others who either hold sceptical views (38 per cent) or are left unsure (14 per cent). Testing this variable against key socio-demographics, the data suggest that whilst men are marginally more likely to believe in the electoral process than not (by 52 per cent to 48 per cent), the opposite is the case for young women (46: 55 per cent). Similarly, respondents from ethnic minority groups are broadly more supportive of elections than not (56: 44 per cent), with white youth by contrast remaining largely negative or ambivalent (48: 52 per cent). Differences also emerge within youth according to social class and educational career. Those from middle class and higher class backgrounds are more likely to believe than not in the electoral process (by a margin of 58: 43 per cent), whilst their manual, unskilled or 'working class' counterparts display opposite views (by 42: 58 per cent); staying on in full-time education clearly has a positive impact on young people's attitudes towards the electoral process, with 54 per cent of 'stayers' exhibiting a strong belief in elections (only 46 per cent not), compared with only 41 per cent of those no longer in full-time education holding similarly positive views (59 per cent taking negative or neutral positions). Table 6 suggests that these differences are statistically significant for social class and on whether or not respondents remain in full-time education.

\section{Table 6: Support for Elections about here}

The young people in this study also recognise that elections as a method of democratic participation are limited, and they are sceptical that the outcomes from elections are positive. Whilst they are more likely to agree (44 per cent) than disagree ( 32 per cent) that elections give voters an opportunity to tell politicians what they think is really important, a large majority of young people (60 per cent compared to 22 per cent) claim that although elections allow voters to express their views, they do not really change anything. Further, noticeably more (44 per cent) disagreed than agreed (28 per cent) that voting could really help to change the way that Britain is governed. Young people were just as likely to agree (42 per cent) as disagree (36 per cent) that elections help to keep politicians accountable for the promises they make. However, that this suggests that almost four out of ten young people disagreed that this key principle of representative government actually works in practice, is a stark indictment of the ability of the political system to win the confidence of young citizens. Again, the caution with which young people support the principle of elections, and their concerns that the outcomes have relatively little value by way of improving governance, would seem to underpin the 'politics focused' approach - that the political system is failing to engage and enthuse young people. 
Significantly, today's youth generation also consider by a large majority that other methods and 'styles' of political participation - such as protest politics and direct action - are important and justified. For instance, 70 per cent agreed that it is right to allow people to organise meetings to protest against the government, with only 8 per cent in disagreement. Perhaps adding weight to the 'alternative value' approach, marginally more respondents agreed ( 27 per cent) than disagreed ( 25 per cent) that being involved in direct action groups like Greenpeace or the Countryside Alliance is a better way of influencing government than being active in political parties that adopt the more conventional style of political action.

We computed a new variable from the original dataset to enable further exploration of young people's views towards voting. ${ }^{27}$ The data (reported in Table 7) indicate that social class exerts a (statistically) significant influence on perceptions, here. Those from manual, unskilled or 'working class' backgrounds have markedly less faith in voting as a vehicle for change than those young people who come from middle or higher social class backgrounds. Education also seems to have a decisive impact on faith in the voting process. There appears to be a considerable gap in perceptions between those who have remained in full-time education and those who left, with the latter group much less positive than statistically expected; belief in the act of voting is much higher amongst those who have attained some educational or work-related qualifications (44 per cent) than those who do not have any qualifications ( 23 per cent). The other variables examined - ethnicity, gender and region in which respondents live - do not appear to have any significant impact on young people's views towards voting.

\section{Table 7: Views Towards Voting about here}

\section{Perception of Political Parties and Professional Politicians}

The relatively guarded position that young people take in relation to the outcomes of elections appears to be driven by a deep-seated scepticism towards those political parties and politicians who vie for their votes and for political office. Our results tend to reinforce those from a number of previous studies that show an apparent disconnection from party politics (Curtice, 2002) - this is very noticeable indeed when we examine young people's responses to many of our questions. In line with the 'politics focused' model, this suggests that the political system is failing to stimulate an enthusiasm amongst young people for the democratic and political process.

Attainers have a relatively low level of party identification (28 per cent, compared to those 59 per cent who report that they do not identify with a political party). Perhaps not surprisingly therefore, nearly all respondents ( 89 per cent) stated that they would not be prepared to give money to a political party, nor would they be prepared to work for a political party in an election campaign ( 84 per cent). Only 2 per cent reported membership of any of the political parties.

Young people appear to hold deeply sceptical views of political parties and of elected politicians, and of the way that they conduct their activities. As Table 8 demonstrates, nearly all respondents agreed with the statement that there is often a big difference between what a party promises it will do and what it actually does when it wins an election. In addition, most concurred with the view that political parties are more interested in winning elections than in governing afterwards. Furthermore, nearly all 
considered that political parties spend too much time bickering with each other and generally dividing the country, while failing to address the really important problems facing the country and those that are of concern to young people in particular. And young people were very critical of political parties that appear to be cynical in their approach to members of the public - parties that are perceived to be more interested in people's votes than their opinions, and who appear to lose touch with people once elected to office.

\section{Table 8: Perception of Political Parties and Professional Politicians about here}

Furthermore, the majority of survey respondents perceive political parties to be remote and incapable of effectively connecting with young people. Respondents were almost twice as likely to agree ( 44 per cent) than disagree ( 26 per cent) with the statement that it's embarrassing when the parties try to appeal to young people during election campaigns. Only a small fraction $(7$ per cent) felt that political parties are good at listening to young people's concerns and then responding to them positively (while 63 per cent disagreed). In addition, the largest group (39 per cent) stated that they considered that Governments do not really care what young people like me think (26 per cent are in disagreement).

A summary variable was computed that covered attitudes to parties and professional politicians. ${ }^{28}$ The data in Table 9 indicate that all bar two of the groups in the study had a uniformly negative view of the political parties - people did not discriminate on the basis of their gender, ethnicity, region of the country in which they lived, or educational qualifications held. The only differences noted were that those remaining in full-time education demonstrated less aversion to the political parties than those no longer in education; likewise those from middle class managerial/ professional households were less sceptical than their manual, unskilled or 'working class' counterparts. However for both these variables, all groups were overwhelmingly negative about professional politicians and political parties.

It is therefore possible to conclude from this that the lack of appetite for mainstream party politics in Britain identified amongst the young people included in our study, suggests that the 'politics focused' model has broad application; whilst there may be some variation in strength of attitude across different youth subgroups, youth as a whole feel alienated from the British political process.

\section{Table 9: Faith in Political Parties and Politicians about here}

\section{Conclusion}

The evidence uncovered through this study indicates that young people in Britain are sufficiently interested in political affairs to dispel the myth that their apparent disconnection from formal politics is as a consequence of their general apathy. Despite very negative perceptions of the world of politics, attainers claim to be interested in political matters and a range of political issues - including a noticeable minority that prioritise the postmaterialist-type issue agenda. And they are also interested in a new style of politics. While they may eschew much of what could be characterised as 'formal' or conventional party politics, there is evidence of some support for a different type of politics that is more participative and direct. These findings lend some weight 
to the 'alternative value' position that there exists a small core of young people in Britain who are engaged with the politics associated with new social movements. However, this should not be over-stated, and it would not be appropriate to explain young people's apparent disengagement with formal politics and the established parties as a consequence of a uniform shift towards a New Politics value system and orientation.

Not only do young people profess an interest in politics, they are also still committed to the idea of elections and the democratic process. There is a civic orientation amongst the young to the democratic process, and representative democracy is generally seen to be a good thing. Taken together, these findings serve to call into question the 'youth focused' approach that implies that young people are politically apathetic, facing various start-up problems that ultimately limit their ability to connect with British politics. Yet, we can find no evidence from our study that young people consider that the democratic process is open to them, and responsive to their needs. And those charged with conducting politics on their behalf - the political parties and professional politicians - are perceived to be self-serving, unrepresentative, and unresponsive to the demands of young people.

This study has found that of the three approaches examined, the 'politics focused' position provides the greater contribution to our understanding of young people's orientation to formal politics in Britain. Despite the presence of variation in political outlook and participation across these youth subgroups indicated by the data (especially in relation to social class, educational history, and gender), attainers as a group do appear to be politically engaged. However, they are highly critical both of the way that the political system operates, and of the way in which professional politicians and established parties conduct their business. This suggests that at the heart of young people's declining election turnout and their apparent disenchantment with Westminster politics is a strong sense of political alienation rather than political apathy - the political system in Britain is failing to provide the stimuli necessary to encourage young people to take a greater role in political life, and as such, faces a crisis of democratic legitimacy. 


\section{Tables}

Figure 1: What is Politics?

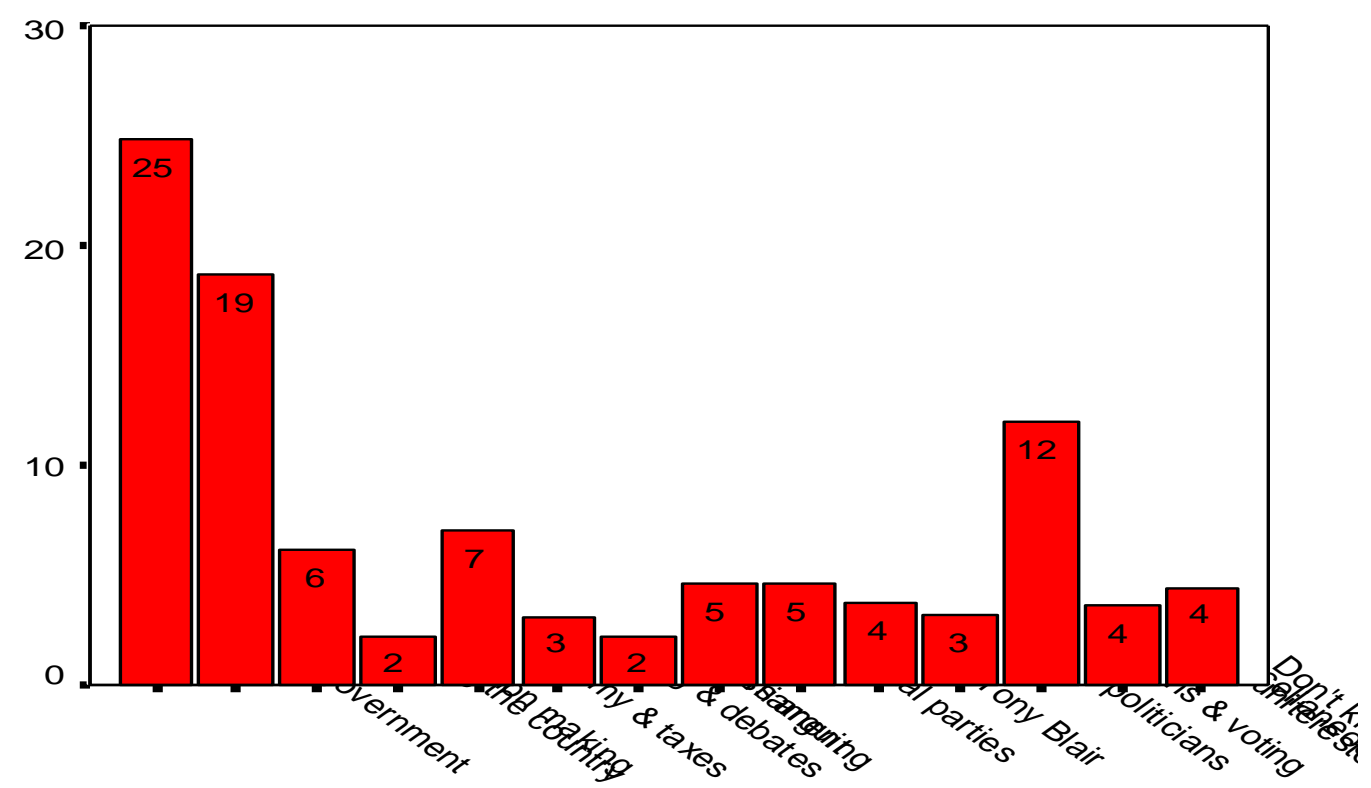

Table 1: Political Interest

\begin{tabular}{lrcrr}
\hline & Chi-square & $\begin{array}{c}\text { Degrees of } \\
\text { freedom }\end{array}$ & Significance & $\begin{array}{r}\text { Phi } \\
\text { coefficient }\end{array}$ \\
\hline Educational & 17.074 & 1 & 0.000 & 0.158 \\
career. & & & & \\
Qualifications. & 8.766 & 1 & 0.003 & -0.114 \\
Gender. & 9.285 & 1 & 0.002 & -0.116 \\
Ethnicity. & 0.515 & 1 & 0.473 & 0.027 \\
Social class & 21.092 & 1 & 0.000 & 0.189 \\
Region & 1.393 & 1 & 0.238 & -0.045 \\
\hline
\end{tabular}


Figure 2: Issues of Most Concern

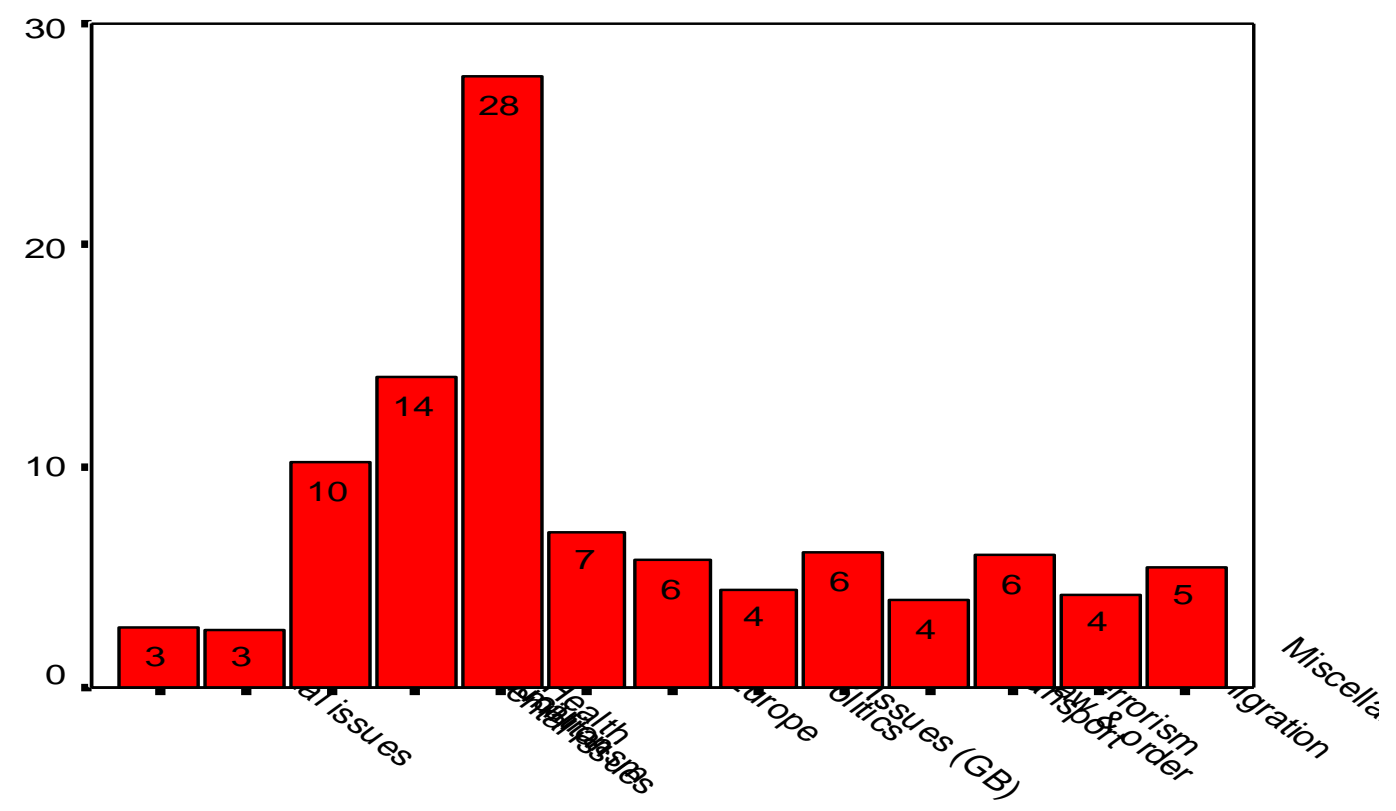

Table 2: Perception of Political Influence

\begin{tabular}{lcc}
\hline & $\begin{array}{c}\text { Agree } \\
\%\end{array}$ & $\begin{array}{c}\text { Disagree } \\
\%\end{array}$ \\
\hline The government generally treats young people fairly. & 23 & 42 \\
$\begin{array}{l}\text { There is a big gap between what young people expect out of life } \\
\text { and what we actually get. }\end{array}$ & 64 & 12 \\
$\begin{array}{l}\text { Young people like me have no say in what the government } \\
\text { does. }\end{array}$ & 62 & 21 \\
$\begin{array}{l}\text { There aren't enough opportunities for young people like me to } \\
\quad \text { influence political parties. }\end{array}$ & 71 & 7 \\
$\begin{array}{l}\text { Being active in politics is a good way to get help for me and my } \\
\text { family. }\end{array}$ & 15 & 41 \\
$\begin{array}{l}\text { It takes too much time and effort to be active in politics and } \\
\text { public affairs. }\end{array}$ & 36 & 30 \\
\hline
\end{tabular}


Table 3: Political Efficacy

\begin{tabular}{lccrr}
\hline & Chi-square & $\begin{array}{r}\text { Degrees of } \\
\text { freedom }\end{array}$ & Significance & $\begin{array}{r}\text { Phi } \\
\text { coefficient }\end{array}$ \\
\hline $\begin{array}{l}\text { Educational } \\
\text { career. }\end{array}$ & 1.923 & 1 & 0.166 & 0.055 \\
Qualifications. & 0.006 & 1 & & \\
Gender. & 0.858 & 1 & 0.940 & 0.003 \\
Ethnicity. & 3.218 & 1 & 0.354 & -0.037 \\
Social class & 5.408 & 1 & 0.073 & 0.071 \\
Region & 0.543 & 1 & 0.020 & 0.100 \\
\hline
\end{tabular}

Table 4: Political Activism

\begin{tabular}{lrcrr}
\hline & Chi-square & $\begin{array}{c}\text { Degrees of } \\
\text { freedom }\end{array}$ & Significance & $\begin{array}{r}\text { Phi } \\
\text { coefficient }\end{array}$ \\
\hline $\begin{array}{l}\text { Educational } \\
\text { career. }\end{array}$ & 10.695 & 1 & 0.001 & 0.129 \\
Qualifications. & 2.946 & 1 & & \\
Gender. & 0.199 & 1 & 0.086 & -0.068 \\
Ethnicity. & 0.355 & 1 & 0.655 & 0.018 \\
Social class & 5.906 & 1 & 0.551 & 0.023 \\
Region & 0.003 & 1 & 0.015 & 0.103 \\
\hline
\end{tabular}

Table 5: Support for the Democratic Process

\begin{tabular}{lcc}
\hline & $\begin{array}{c}\text { Agree } \\
\%\end{array}$ & $\begin{array}{c}\text { Disagree } \\
\%\end{array}$ \\
\hline $\begin{array}{l}\text { All things considered, most elections are just a big waste of } \\
\text { time and money. }\end{array}$ & 24 & 49 \\
$\begin{array}{l}\text { Having regular elections forces politicians to listen carefully to } \\
\text { public opinion. }\end{array}$ & 51 & 27 \\
$\begin{array}{l}\text { I feel/would feel a sense of satisfaction when I vote. } \\
\text { I would be seriously neglecting my duty as a citizen if I didn't } \\
\text { vote. }\end{array}$ & 44 & 22 \\
$\begin{array}{l}\text { I would only vote in an election if I cared who won. } \\
\text { n }\end{array}$ & 47 & 30 \\
\hline
\end{tabular}


Table 6: Support for Elections

\begin{tabular}{lrcrr}
\hline & Chi-square & $\begin{array}{r}\text { Degrees of } \\
\text { freedom }\end{array}$ & Significance & $\begin{array}{r}\text { Phi } \\
\text { coefficient }\end{array}$ \\
\hline $\begin{array}{l}\text { Educational } \\
\text { career. }\end{array}$ & 12.127 & 1 & 0.000 & 0.134 \\
Qualifications. & 0.361 & 1 & & \\
Gender. & 3.062 & 1 & 0.548 & -0.023 \\
Ethnicity. & 0.830 & 1 & 0.080 & -0.067 \\
Social class & 14.194 & 1 & 0.362 & 0.035 \\
Region & 0.371 & 1 & 0.000 & 0.156 \\
\hline
\end{tabular}

Table 7: Views Towards Voting

\begin{tabular}{lrcrr}
\hline & Chi-square & $\begin{array}{r}\text { Degrees of } \\
\text { freedom }\end{array}$ & Significance & $\begin{array}{r}\text { Phi } \\
\text { coefficient }\end{array}$ \\
\hline Educational & 5.177 & 1 & 0.023 & 0.087 \\
career. & & & & \\
Qualifications. & 7.303 & 1 & 0.007 & -0.104 \\
Gender. & 0.105 & 1 & 0.746 & -0.012 \\
Ethnicity. & 0.176 & 1 & 0.675 & -0.016 \\
Social class & 21.400 & 1 & 0.000 & 0.191 \\
Region & 1.759 & 1 & 0.185 & 0.050 \\
\hline
\end{tabular}


Table 8: Perception of Political Parties and Professional Politicians

\begin{tabular}{|c|c|c|}
\hline & $\underset{\%}{\text { Agree }}$ & $\begin{array}{l}\text { Disagree } \\
\%\end{array}$ \\
\hline $\begin{array}{l}\text { There is often a big difference between what a party promises it } \\
\text { will do and what it actually does when it wins an election }\end{array}$ & 87 & 3 \\
\hline $\begin{array}{l}\text { Political parties are more interested in winning elections than in } \\
\text { governing afterwards }\end{array}$ & 69 & 13 \\
\hline $\begin{array}{l}\text { The main political parties in Britain don't offer voters real } \\
\text { choices in elections because their policies are pretty much all } \\
\text { the same }\end{array}$ & 48 & 22 \\
\hline Political parties do more to divide the country than unite it & 41 & 24 \\
\hline Political parties spend too much time bickering with each other & 76 & 9 \\
\hline $\begin{array}{l}\text { In elections, political parties don't tell people about the really } \\
\text { important problems facing the country }\end{array}$ & 50 & 21 \\
\hline $\begin{array}{l}\text { Political parties aren't interested in the same issues that concern } \\
\text { young people }\end{array}$ & 59 & 10 \\
\hline $\begin{array}{l}\text { Parties are only interested in people's votes, not in their } \\
\text { opinions }\end{array}$ & 65 & 14 \\
\hline Those elected to parliament soon lose touch with people & 59 & 12 \\
\hline
\end{tabular}

Table 9: Faith in Political Parties and Politicians

\begin{tabular}{lccrr}
\hline & Chi-square & $\begin{array}{r}\text { Degrees of } \\
\text { freedom }\end{array}$ & Significance & $\begin{array}{r}\text { Phi } \\
\text { coefficient }\end{array}$ \\
\hline $\begin{array}{l}\text { Educational } \\
\text { career. }\end{array}$ & 9.859 & 1 & 0.002 & 0.133 \\
Qualifications. & 0.072 & 1 & & \\
Gender. & 0.529 & 1 & 0.788 & -0.011 \\
Ethnicity. & 0.438 & 1 & 0.467 & -0.031 \\
Social class & 6.870 & 1 & 0.508 & 0.028 \\
Region & 0.934 & 1 & 0.009 & 0.120 \\
\hline
\end{tabular}


(Accepted: 20 May 2005)

\begin{abstract}
About the Authors
Matt Henn, The Graduate School, College of Business, Law and Social Sciences, Nottingham Trent University, Burton Street, Nottingham NG1 4BU, UK; email: matt.henn@ntu.ac.uk
\end{abstract}

Mark Weinstein, The Graduate School, College of Business, Law and Social
Sciences, Nottingham Trent University, Burton Street, Nottingham NG1 4BU, UK;
email: mark.weinstein@ntu.ac.uk

Sarah Forrest, The Graduate School, College of Business, Law and Social Sciences, Nottingham Trent University, Burton Street, Nottingham NG1 4BU, UK; email: sarah.forrest@ntu.ac.uk

This research was supported by the Economic and Social Research Council, R000223598: First-Time Voters' Attitudes towards Party Politics in Britain. We would like to thank the ESRC for this support. We would also like to express our thanks to Rob Vickers and Neil Conant at Nottingham Trent University, both for their preparation of the data and for their general contribution to the project.

\title{
Notes
}

${ }^{1}$ In fact, this figure is somewhat misleading, because it ignores those eligible but not registered to vote. Consequently, the actual voting turnout figure for those eligible to vote at the 2001 General Election is estimated to be only 54 per cent (Whiteley et al., in Norris [ed.], 2001, p.212).

${ }^{2}$ For a discussion of the relative invisibility of youth political research, see Weinstein (2003).

${ }^{3}$ However, this is contested. For instance, Heath and Park (1997) set out to examine whether the popular stereotype of a generation of lazy, uninterested and disengaged young people really does exist. Whilst they did find that the young are an age group who are distinctive in their lack of interest in traditional politics, their results "substantiate previous findings that Thatcher's crusade for a fundamental change in values spectacularly failed to hit the mark" (Heath and Park, 1997, p.19). On the contrary they found that the eighties generation are the generation least likely to identify with Conservative values.

${ }^{4}$ Bhavnani, 1994; White et al., 2000; Henn et al., 2002; Roker and Eden, 2002.

${ }^{5}$ For instance, examining data from the 2001 British Social Attitudes survey, Curtice (2002) notes that there has been a dramatic fall in the numbers of people who believe that there is a great deal of difference between the parties, from 82 per cent and 84 per cent in the General Elections of 1983 and 1987, to only 16 per cent in 2001.

${ }^{6}$ See Henn et al. (2002) for an overview of this position.

${ }^{7}$ Although evidence suggests the presence of significant variation between different BME groups in terms of political outlook and orientation (Saggar, 1999, Purdam et al., 2002).

${ }^{8}$ Attainers are an interesting group for study, particularly so given that they have had minimal formal experience of participating in politics in terms of voting, with the exception of the 2001 General Election. They are therefore relatively politically 
inexperienced in comparison to older people, and are consequently less likely than their older contemporaries to have formed deep-seated views about politics, parties and politicians.

${ }^{9}$ Using this method had the result that not all respondents to our survey were eligible to vote by the time of the general election held on June $7^{\text {th }} 2001$. The electoral register used for this election (and for our study) included all members of households who attained the age of 18 on or after February $16^{\text {th }} 2001$ but before February $16^{\text {th }} 2002$. Hence, by the time of the June election, many of these attainers had not yet reached the voting age of 18. Assuming an even distribution of birthdays for all attainers, this equates to approximately 30 per cent of attainers being 18 by the time of the election.

10 This enabled respondents' postcode locations to be ordered in such a way that they were spread both socio-economically and also geographically in proportion to the number of households in each standard region.

${ }^{11}$ Of course, not every attainer may be captured by this method - indeed, approximately 15 per cent of attainers are not registered to vote (Russell et al., 2002, p.20). Nonetheless, the vast majority of our target group were eligible for inclusion.

1291 members of the original sample list were found to be non-contactable - they were either "not known at that address" or known to be unable to answer the questionnaire due to some other reason. The usable sampling frame was therefore of 3,109 attainers.

${ }^{13}$ In the analysis that follows, certain of our key socio-demographic variables have been recoded to ensure that sub-groups are not too small for meaningful analysis. Thus ethnicity, whilst originally coded using the 2001 British Election Study's 15 category scheme (see footnote 20), was reduced to a two code variable (with 668 respondents re-coded as "All white groups", and 33 re-coded as "All ethnic minority groups"). Social class uses the eight category National Statistics Socio-economic Classification scheme (NS-SEC), recoded into Professional managerial middle class (286) and "Other" classes (309 respondents). Region was initially designed using the Government Office regions 11 category scheme, recoded into a combined Scotland, Wales and London group (162 respondents), with 543 living in "Other" regions. Gender of course remains a two category variable, with 294 male and 411 female respondents.

${ }^{14} \mathrm{We}$ also compared our sample composition with results from several large-scale national surveys commonly used for this purpose in academic studies (Regional Trends (2001) Vol.36; the Annual Abstract of statistics (2002) Vol. 138; The Labour Force Survey (2001)). Our unweighted survey results for gender, social class, and region/nationality closely match the distributions reported across the country, indicating that we can have confidence in the representativeness of our sample results.

${ }^{15}$ Written responses sometimes included more than one theme. Where this was the case, we noted the first item mentioned for the purposes of the quantification of the qualitative data. Thus, items sum to 100 per cent. Readers should note that we use this method throughout in our analysis of open questions.

${ }^{16}$ Interestingly, the 2001 British Election Studies survey reports even higher levels of interest for those aged under 25 years old, at 77 per cent. However this includes people who are older than our attainers. More importantly, the size of this age group in their sample numbers only 53, therefore caution should be exercised when making comparison with our sample of over 700 attainers.

${ }^{17}$ See appendix on the WWW version of this paper for details of how this variable (Political Interest) has been constructed.

18 The appendix on the WWW version of this paper provides details of how the social class variable has been derived. 
${ }^{19}$ It should be noted that these two groups differ significantly in size - of the 681 respondents included in this analysis, only 37 held no such qualifications.

${ }^{20}$ In our survey, respondents were asked as "To which of these groups do you consider you belong?", and their ethnicity was then classified using the 2001 British Election Study's 15 category scheme as either: White British, Other white background, White and Black Caribbean, White and Black African, White and Asian, Other mixed background, Indian, Pakistani, Bangladeshi, Other Asian background, Black Caribbean, Black African, Other Black background, Chinese, Other ethnic group.

${ }^{21}$ The combined sample size of BME groups within our survey was 33, representing $4.7 \%$ of our sample; this compares with the $10 \%$ of the wider population who are aged between 16 and 19 years and also from BME groups (as reported in the Annual Abstract of Statistics (2002) Vol. 138). (Weighting was used so that our aggregate results did not under-reflect the views of people from BME groups.) However, the largest BME groups (Indian, and Asian) had only 7 members each in our survey, and the next largest (Bangladeshi) only 6 respondents. With such small numbers we considered it unwise to conduct differentiated analysis - while our findings may hide any differences that may possibly exist within BME groups, we believe that such disaggregated analysis would generate unreliable results.

${ }^{22}$ Analysis of MORI data published at the same time as this study was conducted indicates that the main concerns of the adult age population (per cent) were NHS/Hospitals (58), Crime/Law and Order (37), Education/ schools (30), Defence/ foreign affairs (18), Race/immigration (15), Public transport (14) (MORI, [2002], p.24).

${ }^{23}$ Interestingly, 54 per cent disagreed with the statement, "we worry too much about the environment today and not enough about people's jobs", with only 23 per cent in agreement - a finding indicating considerable support for the postmaterialist position. Furthermore, using Inglehart's (1990) four item Materialist/ Postmaterialist scale (Materialist: maintaining order in the nation, fighting rising prices; Postmaterialist: giving people more say in important political decisions, protecting freedom of speech), we find that 59 per cent prioritise a mixture of categories, 14 per cent give preference to the two materialist items, but slightly more (18 per cent) gave precedence to postmaterialist concerns.

${ }^{24}$ External efficacy as used here relates to the degree of confidence that young people have in the capacity of the political system to respond to people's actions. For details of how this variable (Efficacy) has been constructed, see appendix on the WWW version of this paper.

${ }^{25}$ The appendix on the WWW version of this paper provides details of how this variable (Activism) has been derived.

${ }^{26}$ See Elections in the appendix on the WWW version of this paper.

${ }^{27}$ See Voting in the appendix on the WWW version of this paper.

${ }^{28}$ See Parties in the appendix on the WWW version of this paper.

\section{References}

Bennie, L. and Rudig, W. (1993) 'Youth and the Environment: Attitudes and Actions in the 1990s', Youth and Policy, 42

Bhavnani, K. (1994) Talking Politics: A Psychological Framing of Views from Youth in Britain. Cambridge: Cambridge University Press

Butler, D. and Stokes, D., (1974) Political Change in Britain. London: MacMillan 
Bynner, J. and Ashford, S. (1994) 'Politics and Participation: Some Antecedents of Young People's Attitudes to the Political System and Political Activity', European Journal of Social Psychology, 24, 223-236

Curtice, J. (2002) 'Is There a General Pattern of Decline?', Turnout in The 2001 and 2002 Elections: What Can Be Done to Reverse the General Decline? And By Whom? Paper presented to the Conference of The Electoral Commission and The Constitution Unit, London, $18^{\text {th }}$ June 2002

Curtice, J. and Park, A. (1999) 'Region: New Labour, New Geography', in P. Norris and G. Evans, (eds.) Critical Elections: British Parties and Voters in Long-term Perspective. London: Sage, 124-47

Dalton, R. (1998) Citizen Politics in Western Democracies. New Jersey: Chatham House

Department of the Environment, Transport and the Regions (1998) 'Modernising Local Government: In Touch With the People', White Paper

European Communities (2003) Analysis of Member States' Replies to the Commission Questionnaire on Youth Participation and Information, Commission Working Paper. Brussels: European Commission

Evans, G., Heath, A. and Payne, C. (1999) 'Class: Labour as a Catch-All Party?' in P. Norris and G. Evans, (eds.) Critical Elections: British Parties and Voters in Longterm Perspective. London: Sage, 87-101

Furlong, A. and Cartmel, F. (1997) Young People and Social Change: Individualisation and Risk in Late Modernity. Buckingham: Open University Press

Harrop, M. (2001) 'An Apathetic Landslide: The British General Election of 2001', Government and Opposition, 36, 295-313

Heath, A. and Park, A. (1997) 'Thatcher's Children?', in R. Jowell et al., (eds) British Social Attitudes: The 14th Report. The End of Conservative Values?. Aldershot: Ashgate

Henn, M., Weinstein, M., and Wring, D. (2002) 'A Generation Apart? Youth and Political Participation in Britain', British Journal of Politics and International Relations, 4 (2), 167-192

Inglehart, R. (1990) Culture Shift in Advanced Industrial Society. New Jersey: Princeton University Press

Kimberlee, R. (1998) 'Young People and the 1997 General Election', Renewal, 6 (2), $87-90$

Kimberlee, R. (2002) 'Why Don't Young People Vote at General Elections?', Journal of Youth Studies, 5 (1), 85-97

Lovenduski, J. (2001) 'women and Politics: Minority Representation or Critical Mass?', in P. Norris (ed), Britain Votes 2001. Oxford: Oxford University Press, 17994

Meguid, B. (2003) Bringing Government Back to the People? The Impact of Political Decentralisation on Voter Engagement in Western Europe. Paper presented to the European Consortium for Political Research Joint Sessions, Edinburgh University, $28^{\text {th }}$ March - 2 $2^{\text {nd }}$ April 2003

MORI (2001) 'How Britain Voted in 2001', British Public Opinion, XXIV (3/4), 3

MORI (2002) 'Most Important Issues' British Public Opinion, XXV (1), 24

Mulgan, G. and Wilkinson, H. (1997) 'Freedom's Children and the Rise of Generational Politics', in G. Mulgan (ed) Life after Politics: New Thinking for The Twenty-First Century. London: Fontana Press

Norris, P. (2001) 'Apathetic Landslide: the 2001 British General Election', in P. Norris (ed), Britain Votes 2001. Oxford: Oxford University Press, 1-25 
Norris, P. (2003) 'Young People and Political Activism: From the Politics of Loyalties to the Politics of Choice?'. Paper presented to the Council of Europe Symposium, Young People and Democratic Institutions: From Disillusionment to Participation, Strasbourg, $27^{\text {th }}-28^{\text {th }}$ November 2003

Norris, P. (1999) 'Gender: A Gender-Generation Gap?', in P. Norris and G. Evans, (eds.) Critical Elections: British Parties and Voters in Long-term Perspective. London: Sage, 148-63

Oppenheim, A.N. (1992) Questionnaire Design, Interviewing and Attitude Measurement. London: Continuum

O’Toole, T., Lister, M., Marsh, D., Jones, S., and McDonagh, A. (2003) 'Tuning Out or Left Out? Participation and Non-participation Among Young People', Contemporary Politics, 9 (1), 45-61

Park, A. (2000) 'Young People and Political Apathy', in R. Jowell et al. (eds) British Social Attitudes: The 16th Report. Who Shares New Labour Values?. Aldershot: Ashgate

Parry, G., Moyser, G., and Day, N. (1992) Political Participation and Democracy in Britain. Cambridge: Cambridge University Press

Pattie, C., Seyd, P., and Paul Whiteley, P. (2003) 'Citizenship and Civic Engagement: Attitudes and Behaviour in Britain', in Political Studies 51 (3) 443-468

Pirie, M. and Worcester, R. (2000) The Big Turn-Off: Attitudes of Young people to Government, Citizenship and Community. London: Adam Smith Institute

Purdam, K., Fieldhouse, E., Kalra, V., and Russell, A. (2002) Voter Engagement Among Black and Minority Ethnic Communities. London: The Electoral Commission

Roker, D., Player, K., and Coleman, J. (1999) 'Young People's Voluntary and Campaigning Activities as Sources of Political Education', Oxford Review of Education, 25 (1\&2), 185-198

Roker, D. and Eden, K. (2002) '...Doing Something': Young People as Social Actors. Leicester: National Youth Agency

Russell, A., Fieldhouse, E., Purdam, K., and Kalra, V. (2002) Voter Engagement and Young People. London: The Electoral Commission

Saggar, S. and Heath, A. (1999) Race: Towards a Multicultural Electorate, in P. Norris and G. Evans, (eds.) Critical Elections: British Parties and Voters in Long-term Perspective. London: Sage, 102-23

Seyd, P., and Whiteley, P. (2002) New Labour's Grassroots: The Transformation of the Labour Party Membership. London: MacMillan

Travis, A. (2005) 'Tories and Lib Dems lag Behind in Postal Vote Count, Survey Shows', The Guardian, 6 May, 1.

Verba, S. and Nie, N. (1972) Participation in America: Political Democracy and Social Equality. New York: Harper and Row

Weinstein, M. (2003) 'Political Activity and Youth in Britain', in G. Taylor and M. Todd (eds), Democracy and Protest: New Social Movements in Liberal Democracies. London: Merlin Press

White, C., Bruce, S. and Ritchie, J. (2000) Young People's Politics: Political Interest and Engagement Amongst 14- to 24- Year-Olds. York: York Publishing Services

Whiteley, P., Clarke, H., Sanders, D., Stewart, M (2001) 'Turnout', in P. Norris (ed) Britain Votes 2001. Oxford: Oxford University Press

Wring, D., Henn, M., and Weinstein, M. (1999) 'Young People and Contemporary Politics: Committed Scepticism or Engaged Cynicism?', in J. Fisher et al., British Elections and Parties Review, Vol. 9. London: Frank Cass Publishers 